\title{
Duration gap analysis revisited method in order to improve risk management: the case of Chinese commercial bank interest rate risks after interest rate liberalization
}

\author{
Marcel Ausloos ${ }^{1,2,3}$ (1) $\cdot$ Qianhui Ma ${ }^{1} \cdot$ Parmjit Kaur $^{4} \cdot$ Babar Syed $^{5} \cdot$ Gurjeet Dhesi $^{5}$
}

Published online: 23 October 2019

(C) The Author(s) 2019

\begin{abstract}
Modern theories attach much attention to interest rate-related problems. We discuss the impacts of the interest rate liberalization, in China, for ten commercial banks of three markedly different ownership types. The methodology is based on revisited interest rate sensitivity analysis, duration analysis and value-at-risk analysis. The situation is examined within both vertical (composition of operating income and interest rate sensitivity gap for the ten banks in the same year) and horizontal (one bank over a 7-year period) aspects. Thereafter, we discuss the present management of interest rate risks by such banks. We conclude with several suggestions on how such commercial banks risk management can be refocused and on how their cases can be used for comforting other banking cases.
\end{abstract}

Keywords Risk management - Commercial banks · Different ownership types · Interest rate sensitivity analysis . Duration gap analysis · Value-at-risk analysis · Horizontal and vertical aspects

\section{Introduction}

Interest rate is one of the most crucial economic variables in economics (Dell'Ariccia et al. 2014). In modern economy, interest rate is regarded as the price of capital, quoting \$https://www.investopedia.com/terms/i/intere strate.asp\$ "being the amount a lender charges for the use of assets expressed as a percentage of the principal. The interest rate is typically noted on an annual basis known as

Communicated by M. Squillante.

Marcel Ausloos

ma683@leicester.ac.uk; marcel.ausloos@ase.ro;

marcel.ausloos@ulg.ac.be

Qianhui Ma

429524673@qq.com

Parmjit Kaur

pkcor@dmu.ac.uk

Babar Syed

syedb3@1sbu.ac.uk

Gurjeet Dhesi

dhesig@1sbu.ac.uk

1 School of Business, University of Leicester, Brookfield, Leicester LE2 1RQ, UK the annual percentage rate (APR)." Its fluctuations not only have a great impact upon capital market and monetary markets, but also influence the whole economy (Drakos et al. 2016). As a result, modern economists attach a great importance to interest rate-related problems. Moreover, governments also take interest rate as one of the most important tools toward macroeconomic regulation and control; at the same time, the authorities put massive emphasis on interest rate and its risk management.

Furthermore, quoting \$https://www.quora.com/Whatdoes-liberalization-of-interest-rates-mean\$, "liberalization of interest rates is the process by which a monetary

2 Department of Statistics and Econometrics, Bucharest University of Economic Studies, 15-17 Dorobanti Avenue, District 1, 010552 Bucharest, Romania

3 Group of Researchers for Applications of Physics in Economy and Sociology (GRAPES), Rue de la Belle Jardinière 483, 4031 Angleur, Belgium

4 Department of Economics and Marketing, Leicester Castle Business School, Hugh Aston, Leicester LE1 9BH, UK

5 School of Business, London South Bank University, 103 Borough Road, London SE1 0AA, UK 
authority relinquishes some control of setting or manipulating interest rates; hence, allowing market forces to mostly determine interest rates. Note: liberalization of interest rates does not necessarily mean the complete absence of interest rates regulations; it simply means monetary authorities have decided to loosen their grip a little bit."

As a significant revolution, interest rate liberalization enables the capital in the market to provide some optimal arrangement which largely promotes the development of a country economy. However, interest rate liberalization also brings huge challenges and risks to the banking industry (Dell'Ariccia et al. 2014).

As for China, a planned economic system has been going on for decades. The interest rate is controlled by the Central Bank, i.e., People's Bank of China. Since 1996, an interest rate liberalization has been going on through several significant reforms which gradually deregulated inter-bank offered rates, bond repurchase rates, foreign currency lending rates, large amount of foreign currency deposit interest rates and financial institutions lending rates. Besides, the People's Bank of China (PBC) increased the frequency of adjusting benchmark interest rates. In its Annual Report PBC 2007-2014, the interest rate is continuously observed to increase six times in 2007 and decrease in 2008 thereafter. The interest rate increased three times in 2011 and decreased three times from 2012 to 2014. In addition, PBC successively adjusted the benchmark interest rates eight times from 2010 to 2014. Thus, this is one signal of China fastening the pace of interest rate liberalization. At this point, it is highly significant for commercial banks to follow the tendency. However, more importantly, enhancing commercial banks level of managing interest rate risks should be highly valued by managers.

Our subsequent analysis is based on data analysis following the reform of interest rate, so-called, liberalization. The literature review is found in Sect. 2, enticing the focus of the intended research, illuminated in Sect. 3 through a set of paragraphs "methodology," in view of the pertinent subsequent analysis.

We aim at analyzing the past situation of Chinese banks and their management of interest rate risks in Sect. 4 at a theoretical level and specifically studying the case of ten Chinese commercial banks in Sect. 5. We stress that we consider different types of ownership, as found in PRC, a distinction also appropriate in various economies around the world.

We conclude with suggestions in Sect. 6. A few appendices contain tables with data. Thus, this research puts forward presently relevant open questions for which we hopefully provide a few answers.

In brief, one has to know how to measure risk, in the context of APR, whence how to find how banks can (theoretically and practically) manage such a risk, and specifically, how various types of commercial banks in China, the main ones, are influenced by government policies. Thus, the "research questions" read:

1. "How efficiently commercial bank interest rate risks can be measured?"

2. "How do changes in interest rates affect bank's performance/management?" Or "How do changes in interest rate affect the income and profitability of the banks?"

3. "How can Chinese commercial banks improve their risk management?" Or "How can the PRC monetary authorities control the interest rate risk to improve the Chinese banks risk management?"

The answers to the questions, as found in Sects. 4 and 5, are based on discussing interest rate sensitivity, duration gap and value-at-risk. We apply the operating income analysis method, the interest rate sensitivity gap analysis, and the duration analysis for this empirical research on "interest rate risks management," following the recent "interest rate liberalization," in a still called "emerging country," China. To do so, ten commercial banks serve as support of our discussion and arguments.

\section{Literature review}

Since 1662, the representatives of interest rate liberalization theory include William Petty, John Locke and Dudley North. Petty (1662) suggests that the demand and supply determine the interest rate (Vaggi and Groenewegen 2016). The same theory was approved by Locke (1692) in his anonymous book (Hayek 2005). Specifically, Locke holds the thought that interest rate is the price of monetary capital; it is the same as other products prices to be decided by demand and supply on a market. If the government tries to control the interest rate by law and violates the objective laws of capital flows, this causes chaos in an economy. However, North (1691) regards currency and loaned capital separately (Chisholm 1911): he thinks that the determination of interest rate is the demand and supply of loaned capital; besides, the only way to adjust interest rate is the market; a government intervention is invalid and only breaks the economic operation. In his (though anonymous!) tract, North points out that to decrease interest rate for promoting economy by law or to increase interest rate for excessive consumption is (alas, our word) done in vain.

Shaw (1973) mentioned financial deepening theory in his famous book. From thereon, it has to be admitted that for developing countries, long-term intervention, including taking control of interest rates and exchange rates, would lead to an unbalance situation for financial instruments, 
would narrow down the financial scale and restrict economic development. In fact, many researchers agree that a financial repression is no longer suitable for the current economy, on the one hand, and governments should gradually loosen up restrictions, so that to promote economic growth, on the other hand. Besides, financial deepening, the increased provision of financial services, could stimulate investors. In so doing, they would enlarge their investment so that to improve the allocation efficiency of social capitals and eventually solve employment problems, as well as economic output problems. In addition, positive effects would also result from a fair competition for all market anticipators, enforce the relationship between supply and demand, better control the interest rates, and promote the allocation of capital.

Disapproving financial repression, Fry (1980) has a great contribution. He uses a sample of 61 developing countries, for the period 1961-1975, in order to estimate the cost ratio of some financial repression. He demonstrates that the growth of actual deposit interest rates could only have positive influences upon the economic development. Through empirical research, he proves that, when the actual deposit interest rate is $1 \%$ lower than the market equilibrium interest rate, the cost of some financial repression is about $0.5 \%$. Therefore, the economy growth would decrease $0.5 \%$. Lanyi and Saracoglu (1983) agree with Fry's opinion. They take 21 developing countries for their samples: data ranging from 1971 to 1980 . The results show that there is a positive relationship between the actual interest rate and the actual increase rate of financial assets as well as with the increase rate of GDP. Gelb (1989) enlarges Lanyi and Saracoglus sample to 34 developing countries. His empirical research proves that when the actual interest rate increases by $1 \%$, the economy would increase from 0.2 to $0.6 \%$. Notice that Roubini and Sala-iMartin (1992) argue that the former mentioned scholars only take one factor into consideration while ignoring other influencing factors and have done a binary regression on 53 countries' cross-sectional data, nevertheless obtaining similar results.

Recently, Papadamou and Siriopoulos (2014) hold the opinion that the development of developing countries' financial market is constrained because governments disobey natural economy laws, leading to breaks in market demand and supply, hence blocking economic development. Moreover, Papadamou and Siriopoulos propose to eliminate financial repression and release the control of interest rate, so that one would reach true financial liberalization. That is to say, the interest rate would wholly reflect the real demand and supply on a market, and as a result, this would increase the market efficiency and accelerate a rapid development of the economy. Briefly concluding here, researchers who agree with a concept of financial deepening (Shaw 1973), i.e., an increased ratio of liquid money supply (to GDP or to some price index), all prove that the growth of actual interest rates would result in an increase of the economy. Additionally, the governments should support financial liberalization by perfecting financial supervision and market mechanisms.

In contrast, Hellmann et al. (1997) hold the opposite opinion. They propose the theory of financial restraint, in which the financial restraints implemented by governments could promote the development of a financial market and reach economic growth. It can be stressed that the financial deepening theory is not suitable for all areas. Take developed countries as examples. In order to get more customers, it is common knowledge that the competition among commercial banks becomes very severe day by day. Under these circumstances, commercial banks take actions to earn profits by any kind of means. This leads to vicious competition and unsteadily influences the development of the country economy.

To be more specific, for one thing, in order to maintain the stable development of an economy, the government would interfere with the interest rates evolution and keep them at a relatively low level. Moreover, such a government would restrict loan issuing. This attitude is considered to be negative toward economic development. Therefore, the passion of investors would go down as well. For an interest rate low level, savings go down, while money demand goes up; thus, debt increases. This leads to capital demand exceeding supply. As a result, one would think that the government would take actions to allocate limited capitals. That is to say, under these conditions, the profits of small- and medium-sized enterprises are lower than those of state-owned enterprises; the former hardly attract capital. In order to make profits, small- and medium-sized enterprises have to be financed by (not supervised, somewhat illegal) private banks. This reduces the utilization ratio of capitals leading to a negative influence on the economy.

In such a frame of thought, one concludes that only when the governments loosen up the restraint toward financial sources and reach financial liberalization, can the economy positively progress and one get rid of poverty.

In the framework of considerations upon interest rate risk management, western scholars are fond of interest rate sensitivity gap analysis, duration analysis, value-at-risk (VaR) analysis, and dynamic simulation analysis. Let us consider these, respectively.

The interest rate sensitivity gap (IRSG) is the balance between interest rate sensitivity asset and interest rate sensitivity liabilities; IRSG is applied for calculating the influence upon interest rate changes toward net interest incomes of banks. 
It is often suggested that banks would subjectively adjust structure of assets and liabilities ahead of time in order to adhere to the future (expected) trend of interest rate in view of increasing the net interest income (Antoniou et al. 2009; Duan et al. 1999; Kero 2013; Byun and Chang 2015).

Macaulay (1938) put forward the now called Macaulay duration which combined coupon effect and horizon effect, to measure the sensitivity of bond price changes toward interest rate changes. In other words, Macaulay applies weighted averages to calculate the average expiration time of bonds. The duration can be applied not only to a single bond, but also to the whole bond portfolio. Yet, there is no so-called linear relation between bond price and its rate of return. As a result, when interest rate massively changes, the duration is unable to reflect the sensitivity of bond changes toward interest rate changes. Therefore, he introduces convexity, combining convexity and duration to measure bonds interest rate risks.

The VaR (Jorion 1997) is used for quantizing risks: under a certain confidence level, a single financial asset or a portfolio would be in a great loss in the future. Nowadays, many foreign financial institutions apply VaR model as their risk management tool.

For universal coherence, the Basel Committee on Banking Supervision has published regulations for interest rate risk management. For instance, in 1996 (Basel Record 1996), the committee published 12 principles of interest rate risk management. It emphasized that banks should build up all-rounded interest rate risk management mechanism in order to effectively identify, measure and monitor interest rate risk position. In 2004 (Basel Record II 2004), the committee published another document on the principles of interest rate risk management and governance. These principles were commonly summarizing many international banks practice. They include the management mechanism related to interest rate risk and solutions related to bank interest rate risk. The principles in 2004 regulated the measurement and management of commercial banks' interest rate risks. Interest rate is here below considered to have four major aspects: basis risk, yield curve risk, repricing risk, and option risk.

"Finally," and more specifically with respect to our study, different researchers have considered various aspects of China when practicing an interest rate liberalization. Several papers pertaining to "transition countries" can be considered here as also relevant by analogy. Specifically, for China, Haselmann and Wachtel (2007) analyzed the necessity of practicing interest rate liberalization under an open economy perspective. They point out four reasons for practicing an interest rate liberalization: first of all, interest rate could automatically adjust and stabilize the economy; secondly, the governments control toward interest rate is invalid; thirdly, the current control of interest rate has influenced the effective allocation of domestic capital; and lastly, the control of interest rate is adverse to Chinese balance of international payment.

Dell'Ariccia et al. (2014) classify risks that probably happened in Chinese interest rate risk liberalization reform. The first classification is based on time period of risks; their conclusion is similar to that of Agoraki et al. (2011). Another way of classification is based on risks scope of influence and divides risks into microrisks and macrorisks. Besides, these authors also put forward three ways of risk measurements, namely interest rate sensitivity analysis, duration analysis, and beta coefficient analysis.

Delis and Kouretas (2011), considering 16 euro area countries over the period 2001-2008, divide up risk into four basic characteristics, i.e., marketability, fundamentality, relativity, and system stability. In this line of thought, one can compare to current interest rates in China and come to the conclusion that both inter-bank bonds repurchase market rate and China inter-bank offered rate (CHIBOR) are in high degree of marketization; therefore, the basic interest rate of China could be settled down. On the other hand, comparing these two interest rates, interbank bonds repurchase market rate is found to perform better than China inter-bank offered rate, for the four basic characteristics. At last, after a Granger causality test, they conclude that inter-bank bonds repurchase market rate is the best basic interest rate to be set.

Among related works, Agoraki et al. (2011) carried out empirical analysis for 13 Central and Eastern European banking systems over the period 1998-2005, dividing interest rate liberalization risk into phased risk and permanent risk. The phased risk means that the fluctuations in net incomes or net assets happened in the initial stage of interest rate liberalization, while the permanent risk refers to the common interest rate risk. They think that managing interest rate risk, for one thing, needs risk identification from the inside of banks and on-and-off management needs transparent decision making from financial regulation departments and effective market incentives.

More recently, Mihai-Yiannaki and Rios-Morales (2015) thoroughly discussed changes in "operating strategies of the whole (Chinese) banking system, for both nationalized and the private commercial banks," following "the duplication and consecutive cut of the deposit and loan interest rates, together with the simultaneous loosening of the interest rate floating range of their financial institutions." An efficient GARCH $(1,1)$ model, as well justified in Jafari et al. (2007) together with the VaR (Jorion 1997), was used to identify the way the interests are adjusted, in particular the influence of interest rate on risks.

Our study is also closely related to the studies of Korean Banks by Aggarwal et al. (2005), Cui (2016), and of 
Chinese banks by Chi and Fu (2016); both studies proposed the investigation of commercial banks interest rate risk management under the interest rate liberalization. The first study uses the data of monthly interest rate from the International Monetary Fund, where the long-term interest rate is the average yield on National Housing Bonds and the short-term interest rate is the average daily rate on call money. Aggarwal et al. (2005) showed that Korean banks sensitivity was positive for expected, but negative for unexpected interest rate changes during the period of government control. Later, Beutler et al. (2017) concluded that loan growth for private banks was more likely to become sensitive to interest rate changes. In fact, much before, Ahmed et al. (1997) had indicated that interest rate risk management was mainly intensive on the interest rate sensitivity of net income. Gomez et al. (2016) showed that "the cash-flow exposure of banks to interest rate risk, or income gap, affects the transmission of monetary policy shocks to bank lending." The study by Cui (2016) uses the interest rate data and the data of interest-sensitive assets and liabilities of nine banks using the interest-sensitive model; he discovered that the irrational allocation of medium- and long-term assets and liabilities in banking structure also hold a true significant relationship. However, Drehmann et al. (2010) indicated that only using gap analysis would lead to miscalculate the risks for banks. In fact, even though the method takes into account the pricing error, the result will not capture the negative impact on the interest rate on assets quality.

\section{Research methodology (hypotheses)}

In the following, we combine qualitative methods and quantitative methods to substantiate theoretical considerations with facts. We apply qualitative methods in order to analyze the process of Chinese interest rate liberalization as well as the classification of interest rate risks faced by Chinese commercial banks during the process of interest rate liberalization. In line with the above-recalled investigations, we introduce three types of measurements for the management of commercial bank interest rate risk analysis, namely the interest rate sensitivity gap analysis, the duration analysis, and the VaR analysis. This leads to so-called $3+1$ hypotheses.

We pose to argue on the choice of such methods: since the different measurements of interest rate risks lead to various ways or strategies for managing interest rate risks, it seems of interest to observe how much different the results can be. Moreover, it is our aim to select an optimized and suitable way for commercial banks to measure interest rate risks, according to each way characteristics and specifically for commercial banks' practical situation.
It is admitted that the level of risk management in Chinese commercial banks nowadays is a bit in a premature stage, while the management mechanisms are not yet considered to be perfect (Haselmann and Wachtel 2007). Therefore, the interest rate sensitivity gap analysis seems a suitable way of investigation. This mechanism appears to be the most popular way used by commercial banks (Laeven and Levine 2009; Eid 2012).

$\mathrm{H} 1_{0}$ The proposed mechanism to measure the interest rate risk will give information on the financial liberalization policies to be activated for economic efficiency and growth.

Additionally, the duration analysis provides an interesting analyzing process, with all-rounded and scientific results; thus, we add the duration analysis as a supplementary tool for the purpose of assisting commercial banks to measure and manage their interest rate risks.

H2 The duration analysis determines both, either negative or positive, effects of the interest rate on assets quality, income, and profitability of banks.

"Finally," under the current development of Chinese commercial banks, widely applying VaR analysis leads to certain conceptual difficulties, as mentioned here above. However, it is expected that with a deepened development of research, the continuous perfection of interest rate management system, and financial literacy skills improvement of managers, the $\mathrm{VaR}$ analysis might be generally introduced to optimize interest rate risk management in Chinese commercial banks (Haselmann and Wachtel 2007).

$\mathrm{H3}_{\mathbf{0}}$ The VaR analysis might be generally introduced to optimize interest rate risk management in Chinese commercial banks.

Whence,

H4, The Chinese commercial banks improve their risk management using interest rate sensitivity and duration gap analysis as appropriate risk management tools under the present interest rate liberalization.

Ten commercial banks (full list in Sect. 5) have been selected in order to evaluate interest rate risks during 2008-2014. This time period contains the latest increase and decrease in interest rates. These ten commercial banks include three different kinds of commercial banks (see Sect. 5), commonly accepted to be representative and valuable. Data used in this paper are collected from the ten banks' balance sheets and their income statements from 2008 to 2014; they provide some information on assets, liabilities, and profits. Table 7 in "Appendix 1" presents the deposit and loan benchmark interest rate in these 
financial institutions from 2008 to 2014. These ten commercial banks include three different kinds of commercial banks (see Sect. 5), commonly accepted to be representative and valuable. Furthermore, this paper uses the deposit benchmark interest rate of RMB in financial institutions from Peoples Bank of China as the liability interest rate of commercial banks, while the loan benchmark interest rate of RMB in financial institutions from Peoples Bank of China is used for the asset interest rate of commercial banks.

Finally, to be more specific, this paper vertically contrasts the composition of operating income and interest rate sensitivity gap within the ten banks in the same year while horizontally contrasting the same contents within one bank over a 7-year period. In so doing, it is expected to find out whether the structure of assets and liabilities coincide with the trend of interest rate changes, thereby justifying the ability of interest rate risk management for the three kinds of commercial banks. In addition, China Construction Bank (CCB) will be taken as an example, applying the duration model to analyze its duration gap and what the change of net asset is when interest rate changes.

\section{Measurement and management of interest rate risks}

Interest rate risk is regarded as one of the major financial risks that commercial banks face; therefore, interest rate risk management plays an important part in commercial banks' operation. Specifically, the measurement of interest rate risk is the priority in interest rate risk (Ballester et al. 2011) since regular measurements could enable commercial banks to estimate the influence caused by interest rate changes in a timely way, so that to adjust the commercial banks' structure of assets and liabilities and increase their net incomes and net assets.

\subsection{Interest rate sensitivity analysis}

The interest rate sensitivity gap concerns the balance between interest rate sensitivity asset and interest rate sensitivity liabilities. Specifically, interest rate sensitivity assets refer to the assets that will expire after a certain time and to the assets for which one needs to reset their interest rates, according to market interest rates: for example, cash or deposits in the Central Bank. Interest rate sensitivity liabilities have the same characteristics as interest rate sensitivity assets, such as loans from the Central Bank.

The measurement of interest rate sensitivity gap depends on its observation period. For instance, a trading financial liability term to repricing is equal to 1 year; if its observation period is set to be 3 months, then the liability is not an interest rate sensitivity liability and cannot be calculated for the gap. However, if the observation period is set to be 1 year, then the liability can be seen as an interest rate sensitivity liability and the liability should be fully counted.

\subsection{Interest rate sensitivity gap analysis equations}

In the interest rate sensitivity gap analysis, two equations are used: one for the interest rate sensitivity gap (IRSG) and the other for the interest rate sensitivity rate (IRSR)

IRSG $=$ IRSA - IRSL,

$\mathrm{IRSG}=\mathrm{IRSA} / \mathrm{IRSL}$,

both in terms of the interest rate sensitivity assets (IRSA) and interest rate sensitivity liabilities (IRSL). The first equation leads to measuring an absolute amount, while the second equation measures a relative quantity.

From these equations, it can be seen that when an interest rate sensitivity asset is larger than an interest rate sensitivity liability, the interest sensitivity gap is larger than 0 , and vice versa. When an interest rate sensitivity asset equals an interest rate sensitivity liability, the interest sensitivity gap equals zero. Meanwhile, as can be seen from the second equation, when an interest rate sensitivity asset is larger than its interest rate sensitivity liability, the interest rate sensitivity rate is larger than 1 , and vice versa. In short, here, the interest rate risk of commercial banks would increase along with the enlargement of the interest rate sensitivity rate.

\subsection{Principle of interest rate sensitivity gap management}

Both interest rate sensitivity gap and interest rate sensitivity rate can be used to measure interest rate risks; furthermore, they are complementary. That is to say, when the interest rate sensitivity gap is positive, the interest rate sensitivity rate is definitely larger than 1 , and vice versa. On the other hand, the interest rate sensitivity gap shows how much the deficits can be. Thus, when commercial banks manage their interest rate risks, both measures are useful.

As for Eq. (1), one can write the net interest income changes (NIIC) as the "weighted difference equation":

$\mathrm{NIIC}=($ IRSA $*$ AIRC $)-($ IRSL $*$ LIRC $)$,

in terms of the interest rate sensitivity asset times the asset interest rate changes (AIRC), on the one hand, and of the interest rate sensitivity liability times the liability interest rate changes (LIRC), on the other hand. 
Thus, if banks face similar (assets and liabilities) interest rate changes, the one encountering the largest risk is when its absolute value of interest rate sensitivity gap is the greatest, i.e., when the interest rate sensitivity rate much deviates from 1. Consequently, commercial banks need to forecast the future trend of interest rates accurately so that to manage its structure of assets and liabilities in advance and finally take advantage of interest rate changes in order to earn profits from net interest rate income, instead of making losses. This is summarized in Table 1. According to Table 1, when the prediction of interest rate has an increasing trend, banks should adjust their structure of assets and liabilities in view of keeping the interest rate sensitivity gap positive. This can increase the interest rate income to the point of becoming larger than the amplitude of the interest rate expenditure, because the interest rate growth would bring an increase in the net interest rate income. When the trend of interest rate is expected to decrease, banks should keep the interest rate sensitivity gap in the negative realm. Then, the reduced range of interest rate income would be less than that of interest rate expenditure, whence banks would increase their net interest rate income as well.

\subsection{Duration analysis: duration and modified (differential) duration}

Duration measure analysis was intuitively proposed by Macaulay (1938). It was first used to calculate the expired date of fixed income bonds and to measure the sensitivity of bond prices toward interest rate changes. After the 1970s, many western banks used the duration analysis as their main tool for measuring the actual payback period of all fixed income financial instruments and the sensitivities of fixed income instruments prices toward interest rate changes. Since then, the duration analysis has been one of the most important methods for managing interest rate risks in commercial banks.

The duration analysis equation reads

Table 1 Sketch of the relationship between interest rate changes (IRC), sensitivity gap (SG), sensitivity rate (SR), and net interest income changes (NIIC)

\begin{tabular}{llll}
\hline IRC & SG & SR & NIIC \\
\hline Increase & Positive & $>1$ & Increase \\
& Negative & $<1$ & Increase \\
& Zero & $=0$ & Invariant \\
Decrease & Positive & $>1$ & Decrease \\
& Negative & $<1$ & Increase \\
& Zero & $=0$ & Invariant \\
\hline
\end{tabular}

$D_{t}=\frac{1}{\mathrm{PV}} \sum_{i=1}^{T} \frac{C_{t}}{(1+i)^{t}} t$

in which $D_{t}$ is the "duration" and $C_{t}$ refers to the cash flow of fixed income instruments at time $t ; T$ refers to the expiry date of the financial instrument; $i$ means the discounted rate which is usually the market interest rate at time $t$; and PV means the "present (or timely) value" of the financial instrument

$\mathrm{PV}=\sum_{i=1}^{T} \frac{C_{t}}{(1+i)^{t}}$.

From the above duration equation, Eq. (4), it can be seen that when a single fixed income instrument has much cash flow in the early stage of a validity period, its duration will be accordingly shorter. Usually, a modified (differential) duration measure $D^{*}$ is defined (from now on, for conciseness we drop the "index" $t$, if there is no confusion) in terms of $\mathrm{PV}$ and $i$,

$D^{*}=-\frac{1}{\mathrm{PV}} \frac{\Delta \mathrm{PV}}{\Delta i}$

$D=\sum_{i=1}^{n} \frac{\mathrm{PV}_{i}}{\mathrm{PV}} D_{i}$

where $\Delta$ means the first-order variation. As mentioned before, the duration not only can be used to measure a single financial instrument interest rate risk, but can be also applied to financial instruments portfolio. Then, the "portfolio duration" is the weighted average of the specific duration of a financial instrument, where the weight is the ratio between each financial instrument market price and the portfolio market price in which $D_{i}$ refers to the $i$ duration, while $\mathrm{PV}_{i}$ refers to the $i$ market price and $n$ is the number of financial instruments in the portfolio.

\subsection{Duration gap equations}

When the market interest rate changes, commercial banks not only need to consider the changes happening in interest rate incomes and outcomes, i.e., the interest rate sensitivity for assets and liabilities, but also should be concerned with noninterest rate sensitivity on assets and liabilities; indeed, these could run into annoying risks as well. In order to take the interest rate risks of all assets and liabilities, when the interest rate is predicted to be changing, commercial banks need to apply some "duration gap management" method, by adjusting the structure of assets and liabilities, so that one controls the duration gap for increasing market value.

One can write the modified duration gap $\left(D_{\text {gap }}^{*}\right)$ equation in terms of the modified durations, respectively, $D_{\mathrm{L}}^{*}$ and $D_{\mathrm{A}}^{*}$, for the total assets and for the total liabilities, as 
$D_{\text {gap }}^{*}=D_{\mathrm{A}}^{*} \Delta i_{\mathrm{A}}-D_{\mathrm{L}}^{*} \Delta i_{\mathrm{L}} \frac{L}{A} \equiv D_{\mathrm{A}} \frac{\Delta i_{\mathrm{A}}}{1+i_{\mathrm{A}}}-D_{\mathrm{L}} \frac{\Delta i_{\mathrm{L}}}{1+i_{\mathrm{L}}} \frac{L}{A}$

in which $i_{\mathrm{A}}$ and $\Delta i_{\mathrm{A}}$ are the asset interest rate and its variation, respectively, while $i_{\mathrm{L}}$ and $\Delta i_{\mathrm{L}}$ have an immediate understanding: the liability interest rate and its variation, respectively.

\subsection{Principle of duration gap management}

The duration gap management is one of the most important ways for commercial banks assets/liabilities management: it presents the all-rounded interest rate risks for commercial banks (Bierwag et al. 1992). When the duration gap is positive, according to its equation, the product of total asset duration and total asset is larger than that of total liability duration and total liability. Then, if the interest rate decreases, the market value of both total asset and total liability will increase. Moreover, the total assets market value will grow more than the total liability market value. As a result, the net asset will go up accordingly.

If the interest rate increases, on the contrary, the dynamics goes the other way around. On the other hand, if the duration gap is negative, the result will be the opposite. Only when the duration gap is equal to zero, no matter how the interest rate is changing, the market value of total assets and liabilities will change at the same time at the same pace; therefore, the net assets of commercial banks would not change. That is to say, in such a case, there is no interest rate risk for commercial banks.

Combining the modified duration equation and the modified duration gap equation, one obtains a relationship between the changes in commercial banks' net assets $\Delta V$ and the modified duration as well as total assets:

$\Delta V \equiv \Delta A-\Delta L=-A D_{\mathrm{A}}^{*} \Delta i_{\mathrm{A}}+L D_{\mathrm{L}}^{*} \Delta i_{\mathrm{L}} \equiv A D_{\text {gap }}^{*}$

According to Eq. (9), when the interest rate changes, two factors influence the commercial banks' net asset. One is the bank's modified duration gap: the larger the modified duration gap absolute value is, the more changes the commercial bank net assets will have under the given interest rate and asset scale. The other is the value of the commercial bank total asset: the larger the market value is, the more changes in net assets there will be under the given interest rate and certain modified duration gap. Bierwag et al. (1992) suggested that since commercial bank asset scales do not dramatically change, the interest rate risk management of commercial banks should focus on dynamically regulating the structure of assets and liabilities and keeping changes in modified duration gap suitable with interest rates.

\subsection{Value-at-Risk Analysis}

The value-at-risk (Jorion 1997) indicates the greatest predicted losses that investors could afford under a given confidence level (e.g., 95\% in this research). Thereafter, a $\mathrm{VaR}$ analysis is performed to evaluate the greatest losses of given assets or liabilities during a certain time interval and for a certain confidence level $\alpha$, i.e.

$a=\int_{R^{*}}^{\infty} f(R) \mathrm{d} R$

$\mathrm{VaR} \equiv E(R)-R^{*}$,

$\operatorname{Prob}(\Delta R \geq \mathrm{VaR})=1-\alpha$.

In such equations, the confidence level is usually taken to be at $99 \%, 95 \%$ or $90 \% ; f(R)$ is the probability density function of a single financial asset (or an investment portfolio) market value $R ; R^{*}$ is the lowest market value of the single financial asset (or investment portfolio) under $\alpha$ confidence; prob is the probability; VaR means the "valueat-risk" for the $\alpha$ confidence level; and $\Delta R$ is the actual loss for a single financial asset (or an investment portfolio) during the holding time interval. This equation shows that the possibility of actual losses to be larger than the valueat-risk is quite low; thus, applying a $\mathrm{VaR}$ analysis allows to predict the losses if interest rates changes are forthcoming.

\section{Study case: ten Chinese commercial banks}

Recall that we consider ten commercial banks; they are distinguished as being four state-owned commercial banks, three joint-stock commercial banks, and three local commercial banks. The four state-owned commercial banks are Industrial and Commercial Bank of China (ICBC), China Construction Bank (CCB), Bank of China Limited (BOC), and Agricultural Bank of China (ABC). The three jointstock commercial banks are China Merchants Bank (CMB), Shanghai Pudong Development Bank (SHPDB), and China Citic Bank (Citic). The three local commercial banks are Bank of Beijing Co., Ltd. (BOB), Bank of Nanjing (BONA), and Bank of Ningbo (BONI).

A short explanatory note: the reason for choosing these three joint-stock commercial banks is based on Standard and Poor's Ratings Services; these three banks are ranked as the top three in total assets. Based on these ten banks' balance sheets and income statements during 2008-2014, we apply the above operating income analysis method, the interest rate sensitivity gap analysis, and the duration analysis for our empirical research about "interest rate risks management," at the present "interest rate liberalization" time, in such an "Emerging Country." 
It is fair to recall again here that Mihai-Yiannaki and Rios-Morales (2015) looked at earnings data on BOC, $\mathrm{CCB}$, and $\mathrm{CMB}$, on a shorter timescale (between September 2010 and November 2012) than in our case, and from a different risk perspective.

\subsection{Operating income analysis}

\subsubsection{Net interest income in operating income percentage analysis}

According to the income statements of the banks, the percentage of net interest income (NII) in operating income from 2008 to 2014 is reported in Table 2 and Fig. 1

Vertically comparing the data means to compare a given bank net interest income during a time interval, and next to compare the average data of all banks. According to Table 2 and Fig. 1, during the examined 7 years, the average percentage floats near [80\%, 85\%]. This is regarded as a high level. Because of such a high percentage value, when the interest rate changes, the net interest rate income will change accordingly; this might make commercial banks face a great interest rate risk. The reason for this, as can be argued in line with Agoraki et al. (2011), is the major business of Chinese commercial banks is in deposits and loans, the off-balance-sheet activities merely playing a secondary role. In other words, the main operating incomes are interest incomes. In a horizontal analysis, from Table 2 and Fig. 1, e.g., in 2014, comparing different banks' net interest income within one specific year, it is found that the four state-owned banks own more capitals and have more powerfully prone operations than the seven others. Besides, their business scale might be larger than the joint-stock banks and the local commercial banks. It is noticeable that Bank of China (BOC) might dominate in international settlements.

Table 2 Percentage of net interest income (NII) in operating income for the ten considered commercial banks from 2008 to 2014

\begin{tabular}{llllllll}
\hline NII \% & 2008 & 2009 & 2010 & 2011 & 2012 & 2013 & 2014 \\
\hline ICBC & 84.92 & 79.44 & 79.76 & 76.34 & 77.82 & 81.37 & 78.51 \\
CCB & 84.08 & 79.30 & 77.75 & 76.70 & 76.66 & 80.38 & 77.91 \\
BOC & 71.37 & 68.42 & 70.07 & 69.50 & 70.19 & 69.95 & 69.88 \\
ABC & 91.79 & 81.72 & 83.38 & 81.33 & 81.02 & 85.63 & 82.66 \\
CMB & 84.77 & 78.46 & 79.96 & 76.36 & 77.95 & 81.06 & 78.46 \\
SHPDB & 91.24 & 91.08 & 90.67 & 90.46 & 88.44 & 91.00 & 89.97 \\
Citic & 89.88 & 88.19 & 86.32 & 84.61 & 84.40 & 88.13 & 85.71 \\
BOB & 90.12 & 92.10 & 92.60 & 90.56 & 88.52 & 91.61 & 90.23 \\
BONA & 80.53 & 87.30 & 87.11 & 87.26 & 84.43 & 84.98 & 85.56 \\
BONI & 84.93 & 85.11 & 86.51 & 85.78 & 89.11 & 85.52 & 86.80 \\
\hline
\end{tabular}

\subsubsection{Handling charges and commissions income in operating income percentage analysis}

The percentage of handling charge and commissions income in operating income from 2008 to 2012 (\%) is reported for each bank in Table 3 .

As aforementioned, from a "vertical comparison," looking at Table 3 and Fig. 2, it can be seen that the percentage of handling charge and commissions income in operating income tends to be on an increasing trend. In our case, the first five banks kept their percentage at around $13 \%$ in 2008 , while in 2014 the percentage went up to $20 \%$. The last five banks kept their percentages lower than $10 \%$ in 2008, but do generally grow during the 7-year period. Compared to Dell'Ariccia et al.'s (2014) results, these numbers are found to be far away below those found for banks of developed countries. (In their paper, Dell'Ariccia et al. examined United Bank of Switzerland, Royal Bank of Scotland, Bank of America, and Hong Kong and Shanghai Banking Corporation (HSBC).) Dell'Ariccia et al. (2014) show that noninterest incomes take more than $40 \%$ in all operating incomes in developed countries, while noninterest incomes are over $50 \%$ in all these listed international banks. The authors also point out that these banks' major business is in insurance services, investment deal, and investment banks, which clearly provide them with large operating incomes. A "conclusion" will follow below.

Next, when horizontally analyzing the data, it can be observed that state-owned commercial banks have the highest handling charge and commissions, while local commercial banks have the lowest fees. Compared with joint-stock commercial banks and local commercial banks, state-owned commercial banks' off-balance-sheet activities are more boarded in fact. This is mainly because stateowned commercial banks own a much larger capital, which are more likely capable of taking risks, as well as expending new business in other areas. Thus, by vertically and horizontally analyzing the percentage of net interest income, handling charge, and commissions income in operating income, and remembering Dell'Ariccia et al. (2014) remarks, it can be concluded that the operating scale of (such) Chinese commercial banks should be usefully expanded; off-balance-sheet activities income should be taken more into accounts, so that the interest rate risks are in fine reduced.

\subsubsection{Horizontal analysis of interest rate sensitivity gap}

In Table 8 of "Appendix 2," we report the data quoted directly from the ten banks' annual reports at the end of 2014. Starting from such data, next, one takes the benchmark interest rate of deposit and loan in 2014 in order to evaluate each bank's interest rate risks. Among all the 


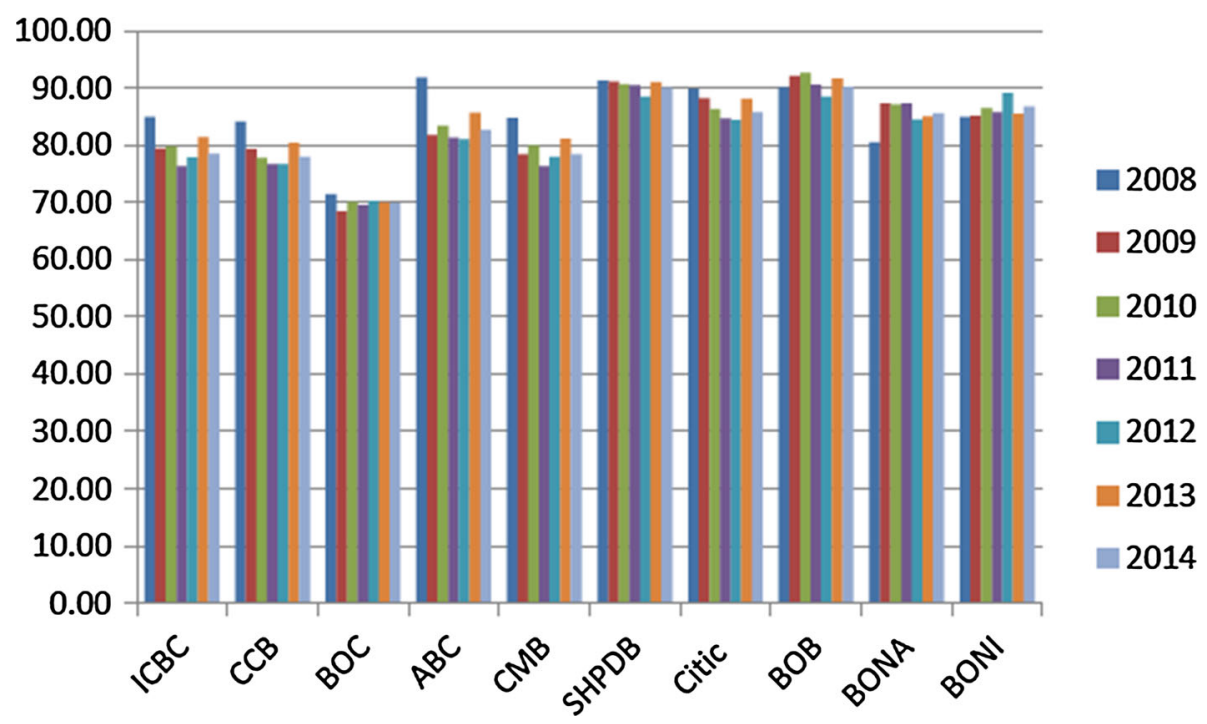

Fig. 1 Histogram of the percentage of net interest income (NII) in operating income from 2008 to 2014 for ten Chinese commercial banks. Industrial and Commercial Bank of China (ICBC), China Construction Bank (CCB), Bank of China Ltd (BOC), and Agricultural Bank of China (ABC) are four state-owned commercial banks.

Table 3 Percentage of handling charge and commissions income (HCCI) in operating income for the ten Chinese commercial banks from 2008 to 2014

\begin{tabular}{lrrrrrrr}
\hline HCCI \% & 2008 & 2009 & \multicolumn{1}{c}{2010} & 2011 & 2012 & 2013 & 2014 \\
\hline ICBC & 14.21 & 17.82 & 19.13 & 21.37 & 19.75 & 17.05 & 19.39 \\
CCB & 14.37 & 17.99 & 20.44 & 21.91 & 20.29 & 17.60 & 19.93 \\
BOC & 17.50 & 19.82 & 19.68 & 19.70 & 19.10 & 19.00 & 19.27 \\
ABC & 11.27 & 16.03 & 15.88 & 18.20 & 17.74 & 14.39 & 16.78 \\
CMB & 14.00 & 15.54 & 15.87 & 16.25 & 17.41 & 15.14 & 16.27 \\
SHPDB & 5.19 & 5.99 & 8.12 & 9.89 & 10.54 & 6.43 & 8.95 \\
Citic & 7.58 & 10.34 & 10.21 & 11.48 & 12.53 & 9.38 & 11.13 \\
BOB & 3.97 & 5.47 & 6.17 & 7.78 & 9.61 & 5.20 & 7.53 \\
BONA & 6.84 & 9.05 & 8.95 & 9.79 & 10.15 & 8.28 & 9.41 \\
BONI & 11.03 & 10.81 & 8.26 & 9.03 & 9.49 & 10.03 & 9.52 \\
\hline
\end{tabular}

variables, the accumulated interest rate sensitivity gap is the sum of all interest rate sensitivity gaps during the given time period. According to Table 8 in "Appendix 2," generally speaking, most commercial banks present a negative interest rate sensitivity gap over a short term, but they present a positive value over the long term. During a 3-month observation period, Citic and BOB show a positive interest rate sensitivity gap. Over a 1-year observation period, each BOC, CMB and SHPDB accumulated interest rate sensitivity gap tends to be positive. During a 5-year observation period, only the BONI accumulated interest rate sensitivity gap is positive. Meanwhile, when the
China Merchants Bank (CMB), Shanghai Pudong Development Bank (SHPDB), and China Citic Bank (Citic) are three joint-stock commercial banks. Three local commercial banks are Bank of Beijing Co. (BOB), Bank of Nanjing (BONA), and Bank of Ningbo (BONI)

observation period is over 5 years, each ICBC, $\mathrm{CCB}, \mathrm{ABC}$ and BONA accumulated interest rate sensitivity gap has a positive value.

According to the data from the People's Bank of China, the benchmark interest rates of deposits and loans tend to decrease. It means that Citic and $\mathrm{BOB}$, for which the sensitivity gap is positive, will go through a loss in net interest incomes; the other eight banks will increase since they present a negative sensitivity gap on a short-term basis. On the other hand, the accumulated interest rate sensitivity gap showing a positive value will cause a reduction in the net interest income (NII) for the long-term asset and liability allocation.

Soto (2004) once analyzed the reasons why commercial banks obtain a negative value for the short term but a positive value for the long term. He suggests that this is because, first of all, most assets of banks are long-term deposits, e.g., enterprise credits and personal housing mortgage loans, while the liabilities mainly are short-term loans, such as current deposits and fixed term deposits. Secondly, since the benchmark interest rate of deposits and loans in financial institutions tends to go up during the recent years, commercial banks forecast that the benchmark interest rate will keep growing, inducing them to adjust their structure of assets and liabilities in order that the interest rate sensitivity gap is positive. However, in order to keep testable the development of the economy, the benchmark interest rate should decrease a little bit.

When looking at Table 8, horizontally, the rank of accumulated interest rate sensitivity gaps absolute value 
Fig. 2 Histogram of the percentage of Handling Charge and Commissions Income in Operating Income from 2008 to 2014 for ten Chinese commercial banks

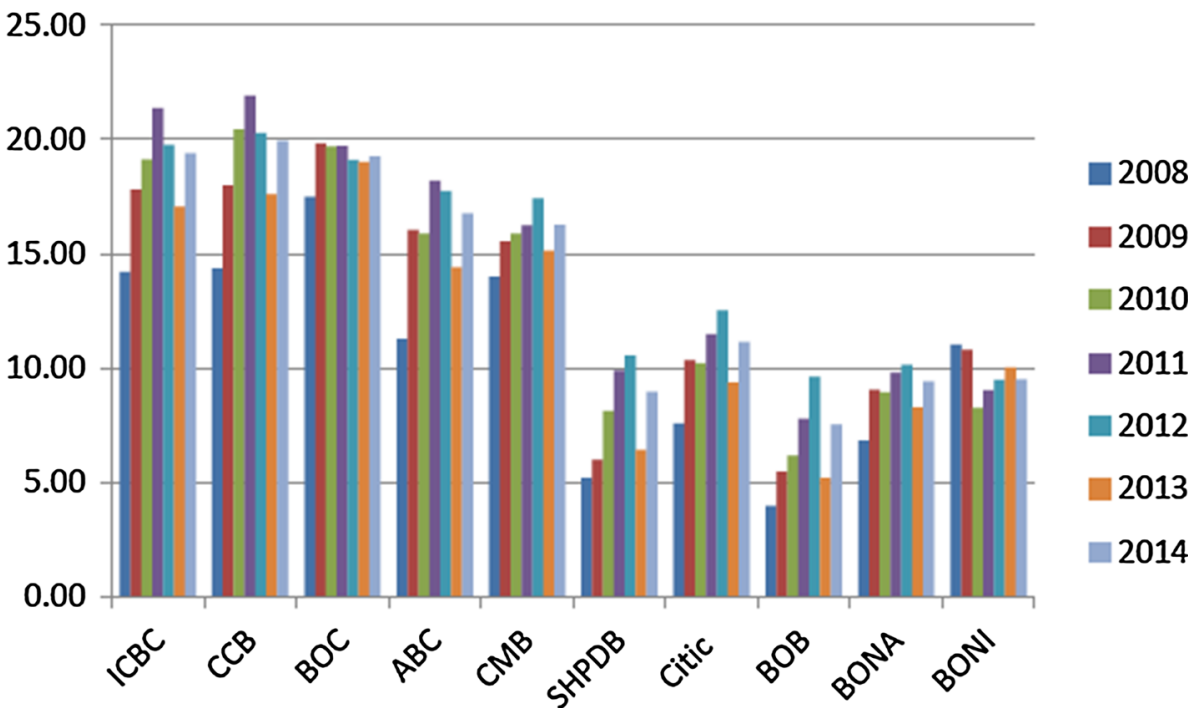

over 5 years is local commercial banks, state-owned commercial banks and joint-stock commercial banks, respectively, whereby three local commercial banks' amounts are over 100 trillion, four state-owned commercial banks' numbers are between 5 trillion and 10 trillion, two joint-stock commercial banks' amounts are less than 2 trillion while SHPDBs number is over 1000 trillion. Because of the downturn trend of interest rate in deposits and loans in 2014, if commercial banks are unable to adjust their interest rate sensitivity gap into positive value, at least, they should keep a low level of positive interest rate sensitivity gap (Eid 2012).

\subsubsection{Vertical analysis of interest rate sensitivity gap}

As mentioned before, we select the China Construction Bank (CCB) as a representative case, in order to calculate its interest rate sensitivity gap and to vertically analyze the data: at the end of each year, CCB presents a negative sensitivity gap for the short term, while showing a positive value for the long term. The pertinent data can be seen in Table 9 of "Appendix 3."

\subsubsection{Interest rate risk measure}

Let us assume for an interest rate risk measurement that the time period is 1 year: let interest rate sensitivity assets and liabilities only include assets or liabilities that expired within 1 year, or that one redecides the interest rate within 1 year. The numerical result obtained from Eq. (3) is reported in Table 4.

When combining Tables 4 and 10 from "Appendix 4," it can be seen that in 2008, the benchmark interest rate of deposits and loans increased considerably, the CCB interest rate sensitivity gap remaining negative. Therefore, CCB
Table 4 Next-year net interest income change (NIIC) for CCB

\begin{tabular}{lr}
\hline At the end of & Next-year net interest income change \\
\hline 2008 & $-2,180,958.30$ \\
2009 & 4866.21 \\
2010 & 0.00 \\
2011 & $-430,596.67$ \\
2012 & $-1,191,047.25$ \\
2013 & $100,011.64$ \\
\hline
\end{tabular}

went through great losses in its net interest income. During the recent years, since the benchmark interest rate of deposits and loans slightly fluctuated but remained in a downturn trend, CCB adjustment in interest rate sensitivity gap seemed not that much constrained.

\subsection{CCB duration analysis}

For the convenience of calculation, two "projection planes" are chosen before doing the pertinent duration analysis for $\mathrm{CCB}$.

\subsubsection{Projection plane 1}

The assets and liabilities are divided into without interest, less than 3 months, 3 months to 1 year, 1-5 years, and more than 5 years; the duration of without interest assets and liabilities are both equal to zero, while for the latter four categories, the expired date or repricing date is set to be the median of the interval, i.e., 1.5 months, 9 months, 3 years and 8 years, respectively. 


\subsubsection{Projection plane 2}

The discounted rate for assets and its interests is taken from the benchmark interest rate for loans in financial institutions, as published on the official Web site of the Peoples Bank of China; he discounted rate for liability, and its interest is taken from the benchmark interest rate of deposit. One usually calculates the interest on the current deposit of Chinese commercial banks quarterly. We use such a quarterly value here when calculating the duration $D$. As a result, the asset discounted rate used for the duration is $6.1 \%$, while the liability discounted rate is $3.1 \%$.

Moreover, the unit for duration is taken as 1 year.

"Appendix 5" is the adapted balance sheet according to the above projection planes. Thus, according to Eqs. (4)(5) and Table 11, it is easy to calculate the duration of CCB interest-bearing assets and liabilities and their corresponding present value for different times. The results are shown in Table 5. Taking 1.5-month cash and deposits in the Central Bank as an example, next combining Eqs. (5) and (7), the duration and its present value could be explicitly calculated.

\subsection{Duration gap analysis}

Based on the data from "Appendix 5" and Table 5, we can obtain numbers for the present value of assets, assets duration, liabilities, the present value of liabilities and liabilities duration of each case and work out the percentage of the present value for each asset and liability. The results are shown in Table 6: the duration of total assets is 0.9781 ; the duration of total liabilities is 0.4834 . It can be seen that the $\mathrm{CCB}$ duration of total assets at the end of 2013 is greater than its duration of total liabilities: this means that the average repayment term of assets is longer, almost the double of average repayment term of liabilities.

At the end of 2012, the benchmark lending rate of financial institution is $6.15 \%$, down $0.15 \%$ on 2014 , and the benchmark deposit interest rate of financial institution is $2.60 \%$, down $0.25 \%$ on 2014 ; the results are in Table 6 . According to the data in the table, using Eq. (8, eq. 3.11), the calculations of the modified duration gap for 1.5 months, 9 months, 3 years, 8 years and overall of CCB at the end of 2013 are $0.0002,-0.0012,-0.0035$, $-0.0280,-0.0024$, as displayed in Table 6. Except for 1.5 month, the modified duration gap is a positive number; all others terms are negative numbers.

\subsection{Theoretical consequence of such interest rate sensitivity gap analysis and duration analysis}

The analysis of the interest rate sensitivity gap allows to conclude that the increasing profit of net interest of CCB in 2014 will be $\simeq 100,011$ millions $\mathrm{RMB}$, while the net asset of $\mathrm{CCB}$ in 2014 will grow to $\simeq 28,692$ millions $\mathrm{RMB}$, according to the result of duration analysis. These two
Table 5 Duration $(D)$ of CCB, rounded to three decimals for (top) interest-bearing assets and (bottom) liabilities with interests and their present value (PV) at the end of 2013

\begin{tabular}{|c|c|c|c|c|c|c|c|c|}
\hline & \multicolumn{2}{|c|}{1.5 months } & \multicolumn{2}{|c|}{9 months } & \multicolumn{2}{|l|}{3 years } & \multicolumn{2}{|c|}{8 years } \\
\hline & $D$ & $\mathrm{PV}$ & $D$ & PV & $D$ & PV & $D$ & PV \\
\hline \multicolumn{9}{|c|}{ Interest-bearing assets } \\
\hline $\mathrm{CDCB}$ & 0.125 & $2,178,298$ & - & - & - & - & - & - \\
\hline DLOB & 0.125 & 278,959 & 0.745 & 102,914 & 2.883 & 1046 & 7.080 & 60 \\
\hline BRpFA & 0.125 & 199,198 & 0.743 & 1062.7467 & - & - & - & - \\
\hline LAC & 0.125 & $3,496,784$ & 0.740 & $2,738,238$ & 2.7785 & 26,663 & 6.458 & 64,571 \\
\hline Investm. & 0.125 & 258,520 & 0.744 & 456,388 & 2.863 & $1,031,587$ & 6.949 & 736,719 \\
\hline Total & 0.125 & $6,411,759$ & 0.740 & $3,298,603$ & 2.861 & $1,041,296$ & 6.910 & 801,350 \\
\hline \multicolumn{9}{|c|}{ Liabilities with interests } \\
\hline LCB & 0.125 & 2214 & - & - & - & - & - & - \\
\hline LLOB & 0.125 & 947,600 & 0.746 & 58,196 & 2.904 & 37,143 & - & - \\
\hline TFL & 0.125 & 11,643 & 0.748 & 9182 & - & - & - & - \\
\hline FASRp & 0.125 & 9574 & 0.740 & 935 & - & - & - & - \\
\hline CD & 0.125 & $7,171,957$ & 0.747 & $2,034,684$ & 2.933 & 663,361 & 7.487 & 6830 \\
\hline IDS & 0.125 & 18,107 & 0.744 & 20,565 & 2.865 & 31,398 & 7.048 & 100,729 \\
\hline Total & 0.125 & $8,161,095$ & 0.747 & $2,123,563$ & 2.929 & 731,902 & 7.076 & 107,559 \\
\hline
\end{tabular}

$C D C B$ cash and deposit in Central Bank, $D L O B$ deposits in and loans to other banks, BRpFA buy-in repurchase financial assets, $L A C$ loans and advances from customers, $L C B$ loans from Central Bank, $L L O B$ liabilities in and loan from other banks, TFL trading financial liabilities, FASRp financial assets sold for repurchase, $C D$ customers deposits, IDS issued debt securities 
Table 6 Duration $D$ of total assets and liabilities

\begin{tabular}{lllllll}
\hline & No interest & 1.5 months & 9 months & 3 years & 8 years & Total \\
\hline Assets & 469,274 & $6,404,546$ & $3,318,981$ & $1,126,319$ & 962,714 & $12,281,834$ \\
PV of Assets & 469,274 & $6,411,759$ & $3,298,603$ & $1,041,296$ & 801,350 & $12,022,281$ \\
Assets PV pcent. & 3.90 & 53.33 & 27.42 & 8.66 & 6.66 & 100 \\
$D$ & - & 0.125 & 0.7403 & 2.8608 & 6.9097 & 0.9781 \\
Liabilities & 275,238 & $8,175,245$ & $2,146,583$ & 761,903 & 106,204 & $11,465,173$ \\
PV of liabilities & 275,238 & $8,161,095$ & $2,123,563$ & 731,902 & 107,559 & $11,399,356$ \\
Liabilities PV pcent. & 2.41 & 71.59 & 18.60 & 6.41 & 0.94 & 100 \\
$D$ & - & 0.125 & 0.7469 & 2.9285 & 7.0761 & 0.4834 \\
$D^{*}$ & - & 0.0002 & -0.0012 & -0.0035 & -0.0280 & -0.0024 \\
\hline
\end{tabular}

Modified duration gap $D^{*}$ of $\mathrm{CCB}$ at the end of 2013; $P V$ present value, $D^{*}$ modified duration gap interest rate risk measures are rather consistent-for interest rate cuts, CCB will profit on net interest and net asset. Furthermore, the data also prove the rationality of such analyses, i.e., to use interest rate sensitivity measures as the major interest rate risk management tools and to use the duration gap as an interesting management method, for commercial banks.

The interest rate level in China is decided by the Central Bank; the main cause for interest rate level changes is China's interest rate policy. However, with interest rate marketization going deeper, the decision-making power on Chinese interest rate levels by the Central Bank will be more limited; it should gradually convert to indirect input causes. It can be admitted that the market factors will become the true cause of influence on the interest rate levels. As a consequence, after the marketization of interest rate, the changes in interest rate will become more frequent. This should require commercial banks to make more systematic or more regular quantitative analysis, as developed above. The banks should dynamically adjust their structure of assets and liabilities in order to defuse the risks induced by interest rate changes, in view of maintaining their net interest and net profit of net assets at their intended level.

\section{Conclusion and recommendations/ discussion}

To conclude, the research has analyzed the risk level and control ability of commercial banks in China under the influence of interest rate liberalization. When measuring interest rate risks, i.e., calculating the sensitivity gap, jointstock commercial banks are found to perform better than both state-owned commercial banks and local commercial banks. This is probably because the joint-stock commercial banks are "newly born" in China; being "more modern" and "already more flexible," they are more capable of managing interest rate risks and grasping the trends of interest rates. A contrario, state-owned commercial banks' assets/liabilities scale ranges are too large to adjust in a short-time term. Similarly, local commercial banks are less capable of managing interest rate risks, since they might be short of related all-rounded and matured regulations.

Therefore, it has been shown that (H10) the duration analysis provides an interesting analyzing process, with allrounded and scientific results, as a tool for the purpose of assisting commercial banks to measure and manage their interest rate risks. Moreover, (H20) the duration analysis determines negative and positive effects of the interest rate on assets quality, income, and profitability of banks. Furthermore, (H30), the VaR analysis is shown to be a valuable technique which could be introduced to optimize interest rate risk management, in Chinese commercial banks. We could also add that the conditional value-at-risk (CVaR) used for the evaluation of portfolios (Cerqueti et al. 2018) could be also implemented at the bank level.

We have shown through a "vertical study" of CCB that the duration analysis can be explicitly performed along our proposed methodology and so allows one to obtain the present values of each asset and liability. It can be noticed from Table 6 that the CCB duration of total assets at the end of 2013 is greater than its duration of liabilities: this implies that the average repayment term of assets is greater (almost twice) than the average of repayment term of liabilities. Also, Table 6 indicates that only for 1.5 month the modified duration gap is positive; all the terms are negative. As a result of a slight decline in the benchmark interest rate of deposits and loans on 2014, CCB net asset for the 1.5-month term will decrease, while the net asset for the 9-month, 3-year, 8-year term and overall will increase. From Eq. (10), one could specifically work out the profit of the value of net asset for CCB in 2014; it is about 28,691.67 million RMB.

As conclusions, in view of the above findings and $\mathrm{H} 40$, let us also present recommendations for reinforcing the interest rate risk management of China and other countries, commercial banks. Let us select four themes. 


\subsection{Set up a steady development strategy}

It is assumed that after interest rate liberalization, commercial banks might enhance their competitiveness by lowering interest rates for loans and increasing deposit interest rates. By doing so, the interest margin would be narrowed down gradually. However, at the same time, in order to afford, respectively, high capital costs, commercial banks have to maintain their profits at a correspondingly high level. At this point, it is highly possible for commercial banks to invest in products that present high income but also high risk. This is obviously far optimal for the development of commercial banks. As a result, it is highly necessary for commercial banks to control their interest margin at a reasonable level so that to improve their abilities of controlling deposits and loans and to accomplish the effective control of profits and costs. This opinion, geared to Chinese commercial banks, is still in line with a nonrecent Demirgüç-Kunt and Detragiache's (1999) paper.

Besides, for Chinese commercial banks especially, it is necessary to set up strategies that are market-oriented and customer-oriented, which is often approved or even recommended by any Chinese government. For one thing, Chinese commercial banks should adjust their products to the current markets. (For the other, they should meet customers' needs to the largest possible extent.) As one would deduce with Haselmann and Wachtel (2007), Chinese commercial banks would become henceforth more competitive and develop better under an appropriate risk management.

\subsection{Bank operation reform according to the market}

When interest rate liberalization happens, the first thing that Chinese commercial banks should do is to make reform inside the bank. Dell'Ariccia et al. (2014) suggested that Chinese commercial banks should modify their operational mechanism. Their suggestion infers that setting up modern banks system while reforming modern corporation system is beneficial to reach interest rate liberalization since banks and corporations would obtain mutual benefits and take risks separately.

In order to reach this goal, commercial banks should expand financial innovation products,-since financial (Ahmed et al. 1997) are capable to lead to great profits for banks, - and for their customers. Besides, increasing the proportion of intermediate business seems to be an efficient process; the current proportion of intermediate business of Chinese commercial banks is less than 20\% (Soto 2004), which is largely lower than that of developed countries- more than $50 \%$ according to Soto (2004). As a result, it can be expected and even believed that there is large potential inside Chinese commercial banks' intermediate business actions.

\subsection{Perfect the inner control in commercial banks}

It is admitted that inner control regulations are among the most important factors toward commercial banks' healthy operations (Ballester et al. 2011). For instance, when a new regulation or document of interest rate liberalization arrives, the manager of a commercial bank should deliver it to all employees and designate specific (and hopefully competent) people to manage it.

Additionally, by the modern means of high technology, commercial banks should be able to calculate the reasonable scales of interest rates and their consequences, much in advance of governmental information, to justify whether there will be compliance or not. Adapting the inner control system of commercial banks, it will be easier to achieve interest rate liberalization and to reduce risks, thereby, very importantly, maintaining and next optimizing their stable operation.

Nevertheless, strictly obeying laws and regulations is another significant factor that should never be ignored.

\subsection{Prevent interest rate risks}

Let us propose this final reasoning through a question (Shehzad and De Haan 2009): after interest rate liberalization, how much of the financial products will be really determined by commercial banks? One should not complain if the interest rate fluctuates at a quicker pace-and be less predictable. In other words, the management of interest rate risk will be more complicated. Therefore, it is highly necessary for commercial banks to actively manage interest rate risks. Commercial banks should set up an interest rate risk management department in view of applying measurement methods suitable for their own situation! Indeed, the phenomenon of increased risk contagion can take place in the banking network like in stock exchanges acting as "integrate-and-fire oscillators" (Bellenzier et al. 2016).

Should one here say that Chinese and other commercial banks need more highly qualified professionals able to do deepened research in both macro- and microeconomy problems such as providing economic situation, sound theoretical and numerical analysis, and in fine policy orientation and strategic planning? They should also be capable of using advanced technology, be aware of modern ideas to manage the structure of their commercial bank assets and liabilities, as well as estimate interest rate risks. 
Applying suitable financial derivative instruments to prevent interest rate risks will also avoid losses caused by interest rate changes, but such a study is outside our present report.

Funding This research was not externally funded.

\section{Compliance with ethical standards}

Conflict of interest The authors declare that they have no conflict of interest.

Human and animal rights We did not use animals, and thus, "all applicable international, national, and/or institutional guidelines for the care and use of animals were followed." We did not use any human, and thus, "all procedures performed in studies involving human participants were in accordance with the ethical standards of the institutional and/or national research committee and with the 1964 Helsinki declaration and its later amendments or comparable ethical standards." In conclusion, "this article does not contain any studies with human participants or animals performed by any of the authors."

Open Access This article is distributed under the terms of the Creative Commons Attribution 4.0 International License (http://creative commons.org/licenses/by/4.0/), which permits unrestricted use, distribution, and reproduction in any medium, provided you give appropriate credit to the original author(s) and the source, provide a link to the Creative Commons license, and indicate if changes were made.

\section{Appendix 1}

The deposit and loan benchmark interest rates in financial institutions from 2008 to 2014 (\%) are given in Table 7.

Table 7 Deposit and loan benchmark interest rate in financial institutions from 2008 to 2014 (\%)

\begin{tabular}{|c|c|c|c|c|c|c|c|c|c|c|}
\hline \multirow{2}{*}{$\begin{array}{l}\text { Adjusting } \\
\text { Date }\end{array}$} & \multicolumn{5}{|l|}{ Deposits } & \multicolumn{5}{|l|}{ Loans } \\
\hline & 3 months & 6 months & 1 year & 3 years & 5 years & $\leq 6$ months & $6-12$ months & $1-3$ years & 3-4 years & $\geq 5$ \\
\hline $2008 / 9 / 16$ & 3.33 & 3.78 & 4.14 & 5.40 & 5.85 & 6.21 & 7.20 & 7.29 & 7.56 & 7.7 \\
\hline 2008/10/9 & 3.15 & 3.51 & 3.87 & 5.13 & 5.58 & 6.12 & 6.93 & 7.02 & 7.29 & 7.4 \\
\hline $2008 / 10 / 30$ & 2.88 & 3.24 & 3.60 & 4.77 & 5.13 & 6.03 & 6.66 & 6.75 & 7.02 & 7.5 \\
\hline $2008 / 11 / 27$ & 1.98 & 2.25 & 2.52 & 5.60 & 3.87 & 5.04 & 5.58 & 5.67 & 5.94 & 6.1 \\
\hline $2008 / 12 / 23$ & 1.71 & 1.98 & 2.25 & 3.33 & 3.60 & 4.86 & 5.31 & 5.40 & 5.76 & 5.9 \\
\hline $2010 / 10 / 20$ & 1.91 & 2.20 & 2.50 & 3.85 & 4.20 & 5.10 & 5.56 & 5.60 & 5.96 & 6.1 \\
\hline $2010 / 12 / 26$ & 2.25 & 2.50 & 2.75 & 4.15 & 4.55 & 5.35 & 5.81 & 5.85 & 6.22 & 6.4 \\
\hline 2011/2/09 & 2.60 & 2.80 & 3.00 & 4.50 & 5.00 & 5.60 & 6.06 & 6.10 & 6.45 & 6.6 \\
\hline 2011/4/06 & 2.85 & 3.05 & 3.25 & 4.75 & 5.25 & 5.85 & 6.31 & 6.40 & 6.65 & 6.8 \\
\hline 2011/7/07 & 3.10 & 3.30 & 3.50 & 5.00 & 5.50 & 6.10 & 6.56 & 6.65 & 6.90 & 7.0 \\
\hline $2012 / 6 / 08$ & 2.85 & 3.05 & 3.25 & 4.65 & 5.10 & 5.85 & 6.31 & 6.40 & 6.65 & 6.8 \\
\hline 2012/7/06 & 2.60 & 2.80 & 3.00 & 4.25 & 4.75 & 5.60 & 6.00 & 6.15 & 6.40 & 6.5 \\
\hline $2014 / 11 / 22$ & 2.35 & 2.55 & 2.75 & 3.35 & 4.00 & 5.60 & 5.60 & 6.00 & 6.00 & 6.1 \\
\hline
\end{tabular}

Mo months, $Y r$ Year 


\section{Appendix 2}

Numerical values of the ten commercial banks' interest rate sensitivity gap (IRSG) at the end of 2014 (million RMB) are given in Table 8, together with their accumulated interest rate sensitivity gap (AIRSG).

\section{Appendix 3}

Table 9 displays the interest rate sensitivity gap (IRSG) analysis numerical results for CCB, from 2008 to 2014 (in millions RMB), together with the corresponding accumulated interest rate sensitivity gap (AIRSG).
Table 8 Ten Chinese commercial banks' interest rate sensitivity gap (IRSG) and accumulated interest rate sensitivity gap (AIRSG) at the end of 2014 (in million RMB)

\begin{tabular}{|c|c|c|c|c|}
\hline Banks & $\leq 3$ months & 3 months to 1 year & $1-5$ years & $\geq 5$ years \\
\hline \multicolumn{5}{|l|}{ ICBC } \\
\hline IRSG & $-1,887,041$ & 976,190 & 584,145 & $1,189,959$ \\
\hline AIRSG & $-1,887,041$ & 910,851 & $-326,706$ & 863,253 \\
\hline \multicolumn{5}{|l|}{$\mathrm{CCB}$} \\
\hline IRSG & $-1,770,699$ & $1,172,398$ & 364,416 & 856,510 \\
\hline AIRSG & $-1,770,699$ & $-598,301$ & $-233,885$ & 622,625 \\
\hline \multicolumn{5}{|l|}{ BOC } \\
\hline IRSG & $-1,686,160$ & $1,703,906$ & 73,372 & 458,081 \\
\hline AIRSG & $-1,686,160$ & 17,746 & 91,118 & 549,199 \\
\hline \multicolumn{5}{|l|}{$\mathrm{ABC}$} \\
\hline IRSG & $-1,555,852$ & $1,296,026$ & $-192,349$ & 997,038 \\
\hline AIRSG & $-1,555,852$ & $-259,826$ & $-452,175$ & 544,863 \\
\hline \multicolumn{5}{|l|}{$\mathrm{CMB}$} \\
\hline IRSG & $-124,219$ & 134,135 & 63,349 & 73,566 \\
\hline AIRSG & $-124,219$ & 9916 & 73,265 & 146,831 \\
\hline \multicolumn{5}{|l|}{ SHPDB } \\
\hline IRSG & $-122,786,504$ & $202,643,393$ & $15,356,334$ & $59,537,051$ \\
\hline AIRSG & $-122,786,504$ & $79,856,889$ & $95,213,223$ & $154,750,274$ \\
\hline \multicolumn{5}{|l|}{ Citic } \\
\hline IRSG & 124,546 & 79,372 & $-32,150$ & 2055 \\
\hline AIRSG & 124,546 & 203,918 & 171,768 & 173,823 \\
\hline \multicolumn{5}{|l|}{ BOB } \\
\hline IRSG & $12,562,561$ & $22,289,775$ & $-1,047,251$ & $55,873,794$ \\
\hline AIRSG & $12,562,561$ & $9,727,214$ & $-10,774,765$ & $45,099,059$ \\
\hline \multicolumn{5}{|l|}{ BONA } \\
\hline IRSG & $-90,112,263$ & $73,178,086$ & $4,382,123$ & $21,887,554$ \\
\hline AIRSG & $-80,112,263$ & $6,934,177$ & $-2,552,054$ & $19,335,500$ \\
\hline \multicolumn{5}{|l|}{ BONI } \\
\hline IRSG & $-30,949,262$ & $29,282,580$ & $2,109,553$ & $14,544,798$ \\
\hline AIRSG & $-30,949,262$ & $-1,666,682$ & 442,871 & $14,987,669$ \\
\hline
\end{tabular}


Table 9 Interest rate sensitivity gap analysis of CCB from 2008 to 2014 (million)

\begin{tabular}{|c|c|c|c|c|c|c|c|}
\hline At the end of & $\mathrm{CCB}$ & Total & Without interests & $\leq 3$ months & 3 months to 1 year & $1-5$ years & $\geq 5$ years \\
\hline \multirow[t]{2}{*}{2008} & IRSG & 330,204 & 19,794 & $-1,536,503$ & $1,149,734$ & 269,811 & 427,368 \\
\hline & AIRSG & & & $-1,536,503$ & $-386,769$ & $-116,958$ & 310,410 \\
\hline \multirow[t]{2}{*}{2009} & IRSG & 422,281 & 45,016 & $-1,846,674$ & $1,135,439$ & 658,492 & 430,008 \\
\hline & AIRSG & & & $-1,846,674$ & $-711,235$ & $-52,743$ & 377,265 \\
\hline \multirow[t]{2}{*}{2010} & IRSG & 467,562 & 35,774 & $-1,635,631$ & $1,446,950$ & 254,594 & 365,875 \\
\hline & AIRSG & & & $-1,635,631$ & $-188,681$ & 65,913 & 431,788 \\
\hline \multirow[t]{2}{*}{2011} & IRSG & 559,020 & 70,115 & $-2,037,268$ & $1,786,844$ & 96,330 & 642,999 \\
\hline & AIRSG & & & $-2,037,268$ & $-250,424$ & $-154,094$ & 488,905 \\
\hline \multirow[t]{2}{*}{2012} & IRSG & 700,905 & 89,594 & $-1,981,441$ & $1,381,678$ & 497,390 & 713,684 \\
\hline & AIRSG & & & $-1,981,441$ & $-599,763$ & $-102,373$ & 611,311 \\
\hline \multirow[t]{2}{*}{2013} & IRSG & 816,661 & 194,036 & $-1,771,699$ & $1,172,398$ & 364,416 & 856,510 \\
\hline & AIRSG & & & $-1,771,699$ & $-598,301$ & $-233,885$ & 622,625 \\
\hline \multirow[t]{2}{*}{2014} & IRSG & 949,609 & 157,114 & $-1,755,646$ & $1,736,008$ & $-90,498$ & 902,631 \\
\hline & AIRSG & & & $-1,755,646$ & $-19,638$ & $-110,136$ & 792,495 \\
\hline
\end{tabular}

$I R S G$ interest rate sensitivity gap, AIRSG accumulated interest rate sensitivity gap

\section{Appendix 4}

The influence of interest rate changes (IRC) upon the net interest income (NII) of CCB from 2009 to 2014 (million RMB) is displayed in Table 10, distinguishing the total assets (TA) and the total liabilities (TL).

\section{Appendix 5}

The actual interest rate and interest-bearing assets and liabilities at the end of 2013 for CCB are given in Table 11.

For example, from Eq. (5), one obtains $\mathrm{PV} \approx 2,170$, 237.

Table 10 Influence of interest rate changes (IRC) toward net interest income (NII) of CCB from 2009 to 2014 (million RMB)

\begin{tabular}{|c|c|c|c|c|c|}
\hline At the end of & $\leq 3$ months & $\begin{array}{l}3 \text { month deposit/loan IRC next } \\
\text { year }\end{array}$ & $\begin{array}{l}3 \text { months to } \\
1 \text { year }\end{array}$ & $\begin{array}{l}1 \text { year deposit/loan IRC next } \\
\text { year }\end{array}$ & $\begin{array}{l}\text { NII change next } \\
\text { year }\end{array}$ \\
\hline \multicolumn{6}{|l|}{2008} \\
\hline TA & $2,056,973$ & 0.99 & $2,155,231$ & 1.35 & \multirow[t]{2}{*}{$-2,180,958$} \\
\hline $\mathrm{TL}$ & $3,593,476$ & 1.53 & $1,005,497$ & 1.62 & \\
\hline \multicolumn{6}{|l|}{2009} \\
\hline TA & $2,775,699$ & -1.71 & $2,224,761$ & -2.16 & \multirow[t]{2}{*}{4866.21} \\
\hline $\mathrm{TL}$ & $4,622,373$ & -1.62 & $1,089,322$ & -1.89 & \\
\hline \multicolumn{6}{|l|}{2010} \\
\hline TA & $3,230,960$ & 0.00 & $2,985,034$ & 0.00 & \multirow[t]{2}{*}{0.00} \\
\hline $\mathrm{TL}$ & $4,866,591$ & 0.00 & $1,535,084$ & 0.00 & \\
\hline \multicolumn{6}{|l|}{2011} \\
\hline TA & $4,477,879$ & 0.49 & $3,532,346$ & 0.50 & \multirow[t]{2}{*}{$-430,596$} \\
\hline $\mathrm{TL}$ & $6,515,147$ & 0.54 & $1,745,502$ & 0.50 & \\
\hline \multicolumn{6}{|l|}{2012} \\
\hline TA & $5,430,809$ & 0.75 & $3,357,890$ & 0.75 & \multirow[t]{2}{*}{$-1,191,047$} \\
\hline $\mathrm{TL}$ & $7,412,250$ & 0.85 & $1,986,212$ & 0.75 & \\
\hline \multicolumn{6}{|l|}{2013} \\
\hline TA & $6,404,546$ & -0.50 & $3,318,981$ & -0.56 & \multirow[t]{2}{*}{100,011} \\
\hline TL & $8,175,245$ & -0.50 & $2,146,583$ & -0.50 & \\
\hline
\end{tabular}

$T A$ total assets, $T L$ total liabilities 
Table 11 Actual interest rate and interest-bearing assets and liabilities at the end of 2013 for $\mathrm{CCB}$

\begin{tabular}{|c|c|c|c|c|c|}
\hline & Actual interest rate $(\%)$ & 1.5 months & 9 months & 3 years & 8 years \\
\hline \multicolumn{6}{|c|}{ Interest-bearing assets } \\
\hline $\mathrm{CDCB}$ & 1.54 & $2,182,521$ & - & - & - \\
\hline DLOB & 2.75 & 279,079 & 105,486 & 1151 & 76 \\
\hline BRpFA & 4.03 & 198,966 & 1079 & - & - \\
\hline LAC & 5.69 & $3,485,517$ & $2,746,432$ & 26,964 & 66,281 \\
\hline Investm. & 3.27 & 258,463 & 465,984 & $1,098,204$ & 896,357 \\
\hline Total & 4.27 & $6,404,546$ & $3,318,981$ & $1,126,319$ & 962,714 \\
\hline \multicolumn{6}{|c|}{ Liability with interests } \\
\hline LCB & 0.98 & 2220 & - & - & - \\
\hline LLOB & 2.35 & 948,479 & 58,520 & 37,955 & - \\
\hline TFL & 1.33 & 11,669 & 9304 & - & - \\
\hline FASRp & 5.67 & 9543 & 918 & - & - \\
\hline $\mathrm{CD}$ & 1.61 & $7,185,234$ & $2,057,323$ & 692,825 & 7633 \\
\hline IDS & 3.41 & 18,100 & 20,518 & 31,123 & 98,571 \\
\hline Total & 1.70 & $8,175,245$ & $2,146,583$ & 761,903 & 106,204 \\
\hline
\end{tabular}

Acronyms of variables are in Table 5
One finds, from Eq. (4), $D=0.125$.

From Eq. (9), one has.

$D_{\text {gap }}^{*} \approx 0.0024$

and from Eq. (10)

$\Delta V \simeq 28,691.67$.

\section{References}

Aggarwal R, Jeon B, Zhao X (2005) Bank exposure to interest rate risks during financial liberalization: evidence from South Korea. Asia-Pac Financ Mark 12(1):61-90

Agoraki M-EK, Delis MD, Pasiouras F (2011) Regulations, competition and bank risk-taking in transition countries. J Financ Stab 7(1):38-48

Ahmed A, Beatty A, Takeda C (1997) Evidence on interest rate risk management and derivatives usage by commercial banks. SSRN Electron J. https://doi.org/10.2139/ssrn.33922

Annual Reports of Peoples Bank of China, 2007-2014

Antoniou A, Zhao HN, Zhou BL (2009) Corporate debt issues and interest rate risk management: hedging or market timing? J Financ Mark 12(3):500-520

Ballester L, Ferrer R, Gonzalez C (2011) Linear and nonlinear interest rate sensitivity of Spanish banks. Span Rev Financ Econ 9(2):35-48

Bellenzier L, Andersen JV, Rotundo G (2016) Contagion in the world's stock exchanges seen as a set of coupled oscillators. Econ Model 59:224-236

Beutler T, Bichsel R, Bruhin A, Danton J (2017) The impact of interest rate risk on bank lending. Working Paper, Study Center Gerzensee, No. 15.05

Bierwag GO, Corrado CJ, Kaufman GG (1992) Durations for portfolios of bonds priced on different term structures. J Bank Finance 16(4):705-714
Byun SJ, Chang KC (2015) Volatility risk premium in the interest rate market: evidence from delta-hedged gains on USD interest rate swaps. Int Rev Financ Anal 40(1):88-102

Cerqueti R, Giacalone M, Panarello D (2018) A generalized error distribution based method for conditional value-at-risk evaluation. In: Corazza M, Durbán M, Grané A, Perna C, Sibillo M (eds) Mathematical and statistical methods for actuarial sciences and finance. Springer, Cham, pp 209-212

Chi Q, Fu S (2016) The impact of the interest rate liberalization on both banks and small firms: evidence from China. Res World Econ 7(2):26-33

Chisholm H (ed) (1911) "North, Sir Dudley". Encyclopædia Britannica. 19, 11th edn. Cambridge University Press, pp 758-759

Cui X (2016) The impact of interest rate marketization on China's commercial banks and its tactics. J Math Finance 6(5):921-929

Delis MD, Kouretas GP (2011) Interest rates and bank risk-taking. J Bank Finance 35(4):840-855

Dell'Ariccia G, Laeven L, Marquez R (2014) Real interest rates, leverage, and bank risk-taking. J Econ Theory 149(1):65-99

Demirgüç-Kunt A, Detragiache E (1999) Financial liberalization and financial fragility. The World Bank. https://doi.org/10.1596/ 1813-9450-1917

Drakos AA, Kouretas GP, Tsoumas C (2016) Ownership, interest rates and bank risk-taking in Central and Eastern European countries. Int Rev Financ Anal 45(5):308-319

Drehmann M, Sorensen S, Stringa M (2010) The integrated impact of credit and interest rate risk on banks: a dynamic framework and stress testing application. J Bank Finance 34(4):713-729

Duan J, Sealey CW, Yan Y (1999) Managing banks' duration gaps when interest rates are stochastic and equity has limited liability. Int Rev Econ Finance 8(3):253-265

Eid S (2012) Monetary policy, risk-taking channel and income structure: an empirical assessment of the French banking system. Bank of France working paper. https://dumas.ccsd.cnrs.fr/ dumas-00643715. Accessed 6 June 2015

Fry MJ (1980) Saving, investment, growth and the cost of financial repression. World Dev 8(4):317-327

Gelb AH (1989) Financial policies, growth, and efficiency. World Bank Publications, Washington 
Gomez M, Landier A, Sraer D, Thesmar D (2016) Banks' exposure to interest rate risk and the transmission of monetary policy, ESRB Working Paper Series, No. 13, ISBN 978-92-95081-40-6. http:// hdl.handle.net/10419/193520. Accessed 6 June 2015

Haselmann R, Wachtel P (2007) Risk taking by banks in the transition countries. Comp Econ Stud 49(3):411-429

Hayek FA (2005) The trend of economic thinking: essays on political economists and economic history. Routledge, New York

Hellmann T, Murdock K, Stiglitz J (1997) Financial restraint: toward a new paradigm. In: Aoki M, Kim H-K, Okuno-Fujiwara M (eds) The role of government in East Asian economic development: comparative institutional analysis. Clarendon Press, Oxford, pp 163-207

Jafari GR, Bahraminasab A, Norouzzadeh P (2007) Why does the Standard GARCH $(1,1)$ model work well? Int J Mod Phys C 18(07):1223-1230

Jorion Ph (1997) Value-at-risk. McGraw-Hill, New York

Kero A (2013) Banks' risk taking, financial innovation and macroeconomic risk. Q Rev Econ Finance 53(2):112-124

Laeven L, Levine R (2009) Bank governance, regulation and risk taking. J Financ Econ 93(2):259-275

Lanyi R, Saracoglu S (1983) Interest rate policies in developing countries. IMF, Occasional Paper, 27

Locke J (1692) Some considerations of the consequences of the lowering of interest, and raising the value of money. In a letter sent to a member of parliament. Awnsham and John Churchill, at the Black-Swan in Pater-Noster-Row. Wallachia Publishers, New York

Macaulay FR (1938) Some theoretical problems suggested by the movements of interest rates, bond yields, and stock prices in the
U.S. since 1856. National Bureau of Economic Research, New York

Mihai-Yiannaki S, Rios-Morales R (2015) Interest rates liberalization or economy control: the case of the Chinese banking system. J Transnatl Manag 20(2):87-106

North D (1691) Discourses upon trade. In: Hollander JH (ed). Johns Hopkins Press, p 1907. https://archive.org/details/sirdudle ynortho00nortgoog. Accessed 6 June 2015

Papadamou S, Siriopoulos C (2014) Interest rate risk and the creation of the Monetary Policy Committee: Evidence from banks and life insurance companies stocks in the UK. J Econ Bus 71:45-67

Petty W (1662) In: The Economic Writings of Sir William Petty, together with the observations upon Bills of Mortality, more probably by Captain John Graunt, ed. Charles Henry Hull. Cambridge University Press, 1899, 2 vols. 2/2/2017. http://oll libertyfund.org/titles/1677. Accessed 6 June 2015

Roubini N, Sala-i-Martin X (1992) Financial repression and economic growth. J Dev Econ 39(1):5-30

Shaw ES (1973) Financial deepening in economic development. Oxford University Press, New York

Shehzad CT, De Haan J (2009). Financial reform and banking crises. In: Conference of the Royal Economic Society, University of Surrey

Soto GM (2004) Duration models and IRR management: a question of dimensions? J Bank Finance 28(5):1089-1110

Vaggi G, Groenewegen P (2016) A concise history of economic thought: from mercantilism to monetarism. Springer, Berlin

Publisher's Note Springer Nature remains neutral with regard to jurisdictional claims in published maps and institutional affiliations. 